\title{
Influence of low-gluten grain crops on beer properties
}

\author{
Valentina Koshova, Roman Mukoid, Anastasia Parkhomenko
}

\author{
National University of Food Technologies, Kyiv, Ukraine
}

\section{Keywords:}

Beer

Wort

Gluten

Buckwheat

Barley

Malt

\begin{tabular}{l} 
Article history: \\
Received \\
12.02 .2020 \\
Received in revised \\
form 21.06 .2020 \\
Accepted \\
30.09 .2020 \\
\hline Corresponding \\
author: \\
Roman Mukoid \\
E-mail: \\
mukoid_roman@ \\
ukr.net \\
\hline
\end{tabular}

DOI:

$10.24263 / 2304-$ 974X-2020-9-3-9

\section{Abstract}

Introduction. The prospects of using buckwheat and buckwheat malt for the production of low-gluten beer are shown.

Materials and methods. Beer wort and beer were made from crushed white buckwheat and buckwheat malt in the ratio of 85, 90, 95 percent barley malt and 15, 10, 5 percent (crushed buckwheat and buckwheat malt). To determine the content of amine nitrogen iodometric method was used, to determine the content of reducing substances the method of Wilshteter-Schudl was used, the protein content was determined by the method of Keldal, the starch content was determined by the method of Evers.

Results and discussion. Gluten is absent in such cereals as buckwheat and rice, and in other cereals the amount of gluten is: corn $80 \mathrm{ppm}$, barley $151 \mathrm{ppm}$, wheat $162 \mathrm{ppm}$. Therefore, for the preparation of low-gluten beer, crushed white buckwheat, buckwheat malt and barley malt are recommended.

The sample with the replacement of $5 \%$ barley malt on buckwheat has the highest content of reducing substances, namely $91.0 \mathrm{~g}$ per $100 \mathrm{~g}$ of extract and amine nitrogen $167.1 \mathrm{mg}$ per $100 \mathrm{~g}$ of extract, the content of ethyl alcohol in the finished beer $3.5 \%$ by weight at mass fraction of the actual extract of $4.83 \%$ by mass.

When replacing barley malt with crushed white buckwheat, it was better to replace it with $5 \%$ barley malt. The content of reducing substances was $86.9 \mathrm{~g}$ per $100 \mathrm{~g}$ of extract, and the content of amine nitrogen was $154.9 \mathrm{mg}$ per $100 \mathrm{~g}$ of extract. The obtained beer of this sample has the best result in terms of alcohol content of $2.9 \%$ by weight and in terms of mass fraction of real extract $-5.53 \%$ by weight.

As the amount of crushed buckwheat and buckwheat malt increases, the amount of reducing substances and amine nitrogen decreases due to the insufficient amount of hydrolytic enzymes in barley malt, under the action of which the above substances are formed. Thus, in the sample with the replacement of 5\% barley malt by buckwheat, the content of reducing substances was $92 \mathrm{~g}$ per 100 $\mathrm{g}$ of extract, and the content of amine nitrogen was $168 \mathrm{mg}$ per 100 $\mathrm{g}$ of extract. Whereas in the sample with a substitution of $15 \%$ barley malt, these figures are $82 \mathrm{~g}$ per $100 \mathrm{~g}$ of extract and $91 \mathrm{~g}$ per $100 \mathrm{~g}$ of extract, respectively.

Conclusions. The best crop for the production of low-gluten beer is crushed white buckwheat and buckwheat malt in a ratio of 95:5. 


\section{Introduction}

Studies of the following cereals were made: barley, wheat, rye, corn, buckwheat in order to select grains with minimum gluten content for the production of low-gluten beer. The content of gluten in crops such as barley, wheat, corn, buckwheat is different [2].

Therefore, studies aimed at determining the minimum amount of gluten in cereals are of particular importance [16, 17]. Wheat (gliadin), rye (secaline) and barley (hordein) prolamines are toxic to the intestinal mucosa of patients with celiac disease $[8,17]$ due to the high content of glutamine (30\%) [4] and proline $(15 \%)$ [5, 6], while prolamins of rice, buckwheat, corn are not toxic due to the lower content of these amino acids [7].

Significant scientific and applied interests are the possibility of using gluten-free raw materials for the preparation of low-gluten beer $[1,3]$.

In study [2] it is recommended to use up to $30 \%$ of extruded buckwheat flakes for brewing wort. The use of such an amount of unmalted raw materials necessarily requires the use of a complex of hydrolytic enzymes [15], which is undesirable in the preparation of lowgluten beer. When using barley malt, this amount of extruded buckwheat flakes will not be able to saccharify the mash, so the optimal amount of buckwheat flakes remains unknown [5], which requires additional research.

Technological, physicochemical, biochemical properties of different varieties of buckwheat were studied and the choice of its optimal amount for brewing was substantiated [20]. Beer wort was prepared in an infused manner with a dry matter content of $8 \%$, the main indicators: reducing substances and amine nitrogen decreased with increasing amount of buckwheat. It would be necessary to investigate in more detail the process of mashing and the amount of unmalted raw materials.

The use of light buckwheat malt for the production of gluten-free beverages: bread kvass, low-alcohol beverages, gluten-free beer has been studied [19]. For example, the made gluten-free beer, for the preparation of which this raw material was used, had the following physicochemical parameters: dry matter content $-11 \%$, alcohol content by volume $-4 \%$, active $\mathrm{pH}-4$, color -18.5 units. EBC, amine nitrogen $-185 \mathrm{mg} / \mathrm{dm} 3$, titratable acidity $0.9 \mathrm{~mol} / \mathrm{dm} 3 \mathrm{NaOH}$. To determine the content of reducing substances that play a significant role in the process of brewing young and finished beer additional research is needed.

For the preparation of low-gluten beer, it is advisable to use buckwheat, as it has optimal physicochemical properties, does not contain gluten and has a unique amino acid composition, which is much better than barley $[10,11]$.

Therefore, for the preparation of wort, and subsequently low-gluten beer as an auxiliary raw material crushed white buckwheat and buckwheat malt was selected [1,2].

The purpose of research is to establish the effect of white buckwheat or buckwheat malt on physicochemical and organoleptic parameters for the production of low-gluten beer.

\section{Materials and methods}

\section{Materials}

Barley malt, buckwheat malt, and crushed white buckwheat were used to prepare beer wort. The mash is prepared in an insistent way [15].

Malt wort was obtained by mashing at various temperature pauses ranging from $45{ }^{\circ} \mathrm{C}$ to $78{ }^{\circ} \mathrm{C}$, followed by filtration, boiling with and hopping, followed by clarification and cooling [12]. 
The finished beer wort was fermented and rambled in the classical way. The finished beer was filtered and physicochemical parameters were determined in it [15].

Pure malt wort made from light barley malt was selected as a control sample.

\section{Methods}

Determination of extractivity in grain raw materials. Extractivities in grain raw materials were performed by the congress method [12].

The essence of the method is to convert to a solution of extractive substances of malt under the action of its personal enzymes, provided that they are close to optimal, followed by separation of the solution and determine its concentration on the Anton Paar analyzer [13].

Determination of starch content in grain raw materials. Determination of starch was carried out by the Evers method. To determine the starch content, a portion of the ground raw material was dissolved at low boil with $1 \%$ hydrochloric acid solution. The resulting clear solution was polarized on a polarimeter using a tube length of $200 \mathrm{~mm}$ [15].

Determination of protein content in grain raw materials. Protein determination was performed by the Keldal method. The essence of the method is that the product sample is decomposed (burned) with sulfuric acid in the presence of a catalyst, and then obtained after decomposition, bound in the form of ammonium sulfate, nitrogen is determined by titration [14].

The nitrogen content (A) as a percentage of the dry matter of barley is calculated by the formula:

$$
\mathrm{A}=\frac{(a-b) \cdot 0.0014 \cdot 100 \cdot 100}{H \cdot(100-w)},
$$

where $\mathrm{a}$ is the amount of sulfuric acid solution taken $(0.1 \mathrm{~mol} / \mathrm{dm} 3), \mathrm{cm} 3$;

$\mathrm{b}-$ is the amount of sodium hydroxide $(0.1 \mathrm{~mol} / \mathrm{dm} 3)$, which is spent on back titration, $\mathrm{cm} 3$;

$\mathrm{w}$ - moisture content of flour, $\%$;

$\mathrm{H}-$ portion of flour, $\mathrm{g}$.

Determination of moisture in grain raw materials. Determination of humidity was performed by drying to constant weight at a temperature of $130^{\circ} \mathrm{C}$ [12].

$\mathrm{W}$ - product moisture, $\%$;

$$
W=\frac{m_{1}-m_{2}}{m_{1}-m_{0}} \times 100 \%
$$

$\mathrm{m}_{0}$ - mass of cups without sample $\mathrm{g}$;

$\mathrm{m}_{1}$ - mass of sample cups before drying, $\mathrm{g}$;

$\mathrm{m}_{2}-$ mass of the sample cups after drying, $\mathrm{g}$.

Determination of physicochemical parameters of beer wort. Determination of physicochemical parameters of beer wort (mass fraction of dry matter, titratable acidity, active acidity, bitterness, color, transparency), as mentioned above, was determined using Anton Paar analyzer [13].

Determination of reducing substances in the wort. Determination of reducing substances in the wort was determined by the method of Wilshteter-Schudl, based on the oxidation of aldose by iodine [15]. 
Determination of amine nitrogen content in wort. The content of amine nitrogen in the wort was determined by iodometric method (according to Pop and Stevens) [12].

The method is based on the ability of amino acids to form soluble complex compounds with copper [12]. Excess copper is filtered off, acetic acid is added to the filtrate, which cleaves copper from the complex compound to form copper acetate, and then potassium iodide is added. When the latter interacts with copper acetic acid, free iodine is released, the amount of which is proportional to the amount of copper, and hence the amount of amine nitrogen [12]. Free iodine is titrated with a solution of sodium thiosulfate in the calculation [12].

Analysis of finished beer. Physicochemical parameters in the finished beer (mass fraction of visible, actual extract, ethyl alcohol, transparency, bitterness) were determined using an Anton Paar analyzer [13].

\section{Results and discussion}

\section{Physicochemical parameters of raw materials}

In samples of different cereals their fractional composition of proteins have been studied [5], the data are given in Table 1.

Fractional composition of buckwheat proteins and some cereals

Table 1 (as a percentage of total protein content)

\begin{tabular}{|l|c|c|c|c|c|}
\hline \multirow{2}{*}{ Factions } & \multicolumn{5}{|c|}{ Grain products } \\
\cline { 2 - 6 } & Buckwheat & Barley & Wheat & Rice & Corn \\
\hline Albumins & $21-24$ & $2,8-6,4$ & $0,5-5,2$ & $5,8-11,2$ & $0-10,0$ \\
\hline Globulins & $42-45$ & $7,5-18,1$ & $0,6-12,6$ & $4,8-9,2$ & $4,5-6,0$ \\
\hline Prolamines & $1,1-1,2$ & $37,2-41,6$ & $35,6-99$ & $4,4-14,0$ & $29,9-55,0$ \\
\hline Glutelins & $10-12$ & $26,6-41,9$ & $0-28,2$ & $63,0-70$ & $30,0-45,0$ \\
\hline
\end{tabular}

According to the obtained results (Table 1), buckwheat and rice are classified as glutenfree cultures and are recommended for use in dietary nutrition for patients with celiac disease [3] (other names - intestinal enteropathy, gluten intolerance, gluten atoxia). This autoimmune disease, according to the World Association of Gastroenterologists, affects about one percent of the world's population [5].

Buckwheat has the best properties for brewing, beer made from buckwheat or by replacing part of the barley malt with buckwheat in taste and color is almost no different from barley.

In the Table 2 it is shown the physicochemical parameters of the studied grain raw materials. 
Physicochemical parameters of grain raw materials

\begin{tabular}{|c|c|c|c|c|c|c|c|c|}
\hline \multirow[b]{2}{*}{ Raw } & \multirow{2}{*}{ 起 } & \multicolumn{2}{|c|}{ Extractivity, \% } & \multicolumn{2}{|c|}{ Starch, \% } & \multicolumn{2}{|c|}{ Protein, \% } & \multirow{2}{*}{ 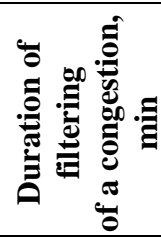 } \\
\hline & & $\begin{array}{l}\text { Air-dry } \\
\text { substance }\end{array}$ & $\begin{array}{c}\text { Dry } \\
\text { substance }\end{array}$ & $\begin{array}{c}\text { Air-dry } \\
\text { substance }\end{array}$ & $\begin{array}{c}\text { Dry } \\
\text { substance }\end{array}$ & $\begin{array}{l}\text { Air-dry } \\
\text { substance }\end{array}$ & $\begin{array}{c}\text { Dry } \\
\text { substance }\end{array}$ & \\
\hline $\begin{array}{l}\text { Barley } \\
\text { malt } \\
\end{array}$ & 3,6 & 74,53 & 77,32 & 62,8 & 65,6 & 10,1 & 11,15 & 30 \\
\hline $\begin{array}{l}\text { Buckwheat } \\
\text { malt }\end{array}$ & 4,2 & 61,4 & 66,7 & 66,2 & 68,5 & 12,3 & 12,9 & 45 \\
\hline $\begin{array}{l}\text { Crushed } \\
\text { white } \\
\text { buckwheat }\end{array}$ & 12,7 & 67,2 & 69,8 & 70,3 & 72,1 & 13,5 & 14,7 & 45 \\
\hline
\end{tabular}

The dry matter extract content of light barley malt exceeds the content of buckwheat malt and crushed buckwheat and is $77.32 \%$. But the highest protein content was found in crushed buckwheat, which is $14.7 \%$, which is $21.8 \%$ higher than the content in barley malt and $12.4 \%$ in buckwheat.

The process of filtering the wort is much faster when using barley malt, but when using buckwheat malt or white buckwheat, the filtration process is not much longer than when using barley malt. This is due to the fact that collapsed buckwheat does not have a fruit shell, which leads to a decrease in the height of the filter layer, while slowing down the filtration rate $[12,15]$.

\section{Analysis of beer wort}

Physicochemical parameters of pure malt wort from light barley malt (control) with partial replacement of barley malt with crushed white buckwheat are given in Table 3 .

Table 3

Physicochemical parameters of malt wort with partial replacement of barley malt with crushed white buckwheat

\begin{tabular}{|c|c|c|c|c|c|c|c|c|}
\hline \multirow{2}{*}{$\begin{array}{c}\text { Mash } \\
\text { (barley malt + } \\
\text { crushed white } \\
\text { buckwheat) }\end{array}$} & \multirow{2}{*}{ 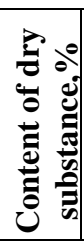 } & \multirow{2}{*}{$\mathrm{pH}$} & \multicolumn{2}{|c|}{$\begin{array}{l}\text { Titrated acidity, } \\
\text { mol/dm } \mathbf{d m}^{3} \mathrm{NaOH}\end{array}$} & \multicolumn{2}{|c|}{$\begin{array}{c}\text { Content of } \\
\text { reducing } \\
\text { substances, } \mathrm{g}\end{array}$} & \multicolumn{2}{|c|}{$\begin{array}{l}\text { Content of amine } \\
\text { nitrogen, } \mathrm{mg}\end{array}$} \\
\hline & & & $\begin{array}{c}\text { per } 100 \\
\mathrm{~cm}^{3} \text { of } \\
\text { wort }\end{array}$ & $\begin{array}{c}\text { per } \\
100 \mathrm{~g} \text { of } \\
\text { extract }\end{array}$ & $\begin{array}{c}\text { per } 100 \\
\mathrm{~cm}^{3} \text { of } \\
\text { wort }\end{array}$ & $\begin{array}{c}\text { per } \\
100 \mathrm{~g} \text { of } \\
\text { extract }\end{array}$ & $\begin{array}{c}\text { per } 100 \\
\mathrm{~cm}^{3} \text { of } \\
\text { wort }\end{array}$ & $\begin{array}{c}\text { per } \\
100 \mathrm{~g} \text { of } \\
\text { extract }\end{array}$ \\
\hline $\begin{array}{l}\text { Control pure malt } \\
\text { wort }\end{array}$ & 14 & 5,9 & 2,1 & 5,1 & 10,3 & 71,3 & 22,12 & 152,9 \\
\hline $\begin{array}{l}95 \% \text { barley malt } \\
+5 \% \text { crushed white } \\
\text { buckwheat }\end{array}$ & 14 & 6,1 & 4,0 & 9,2 & 12,0 & 86,9 & 22,4 & 154,9 \\
\hline $\begin{array}{l}90 \% \text { barley malt } \\
+10 \% \text { crushed white } \\
\text { buckwheat }\end{array}$ & 14 & 6,1 & 4,1 & 9,5 & 11,0 & 81,4 & 18,2 & 124,4 \\
\hline $\begin{array}{l}85 \% \text { barley malt } \\
+15 \% \text { crushed white } \\
\text { buckwheat }\end{array}$ & 14 & 6,1 & 4,2 & 9,7 & 11,7 & 80,8 & 12,6 & 87,1 \\
\hline
\end{tabular}


The best results in terms of reducing substances and amine nitrogen showed a sample of wort, which was prepared from barley malt and crushed white buckwheat in a ratio of 95:5, respectively. As the content of crushed white buckwheat increases, the content of reducing substances and amine nitrogen decreases, this is due to the fact that white buckwheat lacks enzymes and therefore reducing substances and amine nitrogen cannot be extracted into solution (pure malt wort) [7]. Therefore, in the preparation of low-gluten beer, it is proposed to use wort with partial replacement of barley malt with crushed white buckwheat in the amount of $5 \%$.

Physicochemical parameters of malt wort with partial replacement of barley malt with buckwheat malt are given in Table 4.

Table 4

Physicochemical parameters of malt wort with partial replacement of barley malt with buckwheat malt

\begin{tabular}{|c|c|c|c|c|c|c|c|c|}
\hline \multirow{2}{*}{$\begin{array}{c}\text { Mash } \\
\text { (barley malt }+ \\
\text { buckwheat malt) }\end{array}$} & \multirow{2}{*}{$\begin{array}{c}\text { Content } \\
\text { of dry } \\
\text { substance, \% }\end{array}$} & \multirow{2}{*}{ pH } & \multicolumn{2}{|c|}{$\begin{array}{l}\text { Titrated acidity, } \\
\text { mol/d/m } \mathbf{d m}^{3} \mathrm{NaOH}\end{array}$} & \multicolumn{2}{|c|}{$\begin{array}{c}\text { Content of } \\
\text { reducing } \\
\text { substances, } g\end{array}$} & \multicolumn{2}{|c|}{$\begin{array}{c}\text { Content of } \\
\text { amine nitrogen, } \\
\text { mg }\end{array}$} \\
\hline & & & \begin{tabular}{|c} 
per \\
$100 \mathrm{~cm}^{3}$ \\
of wort
\end{tabular} & $\begin{array}{c}\text { per } \\
100 \mathrm{~g} \text { of } \\
\text { extract }\end{array}$ & $\begin{array}{c}\text { per } \\
100 \mathrm{~cm}^{3} \\
\text { of wort }\end{array}$ & $\begin{array}{c}\text { per } \\
100 \mathrm{~g} \text { of } \\
\text { extract }\end{array}$ & \begin{tabular}{|c|} 
per \\
$100 \mathrm{~cm}^{3}$ \\
of wort
\end{tabular} & $\begin{array}{c}\text { per } \\
100 \mathrm{~g} \text { of } \\
\text { extract }\end{array}$ \\
\hline $\begin{array}{l}\text { Control pure malt } \\
\text { wort }\end{array}$ & 14 & 5,9 & 2,1 & 5,1 & 10,3 & 71,3 & 22,1 & 152,9 \\
\hline $\begin{array}{l}95 \% \text { barley malt } \\
+5 \% \text { buckwheat } \\
\text { malt }\end{array}$ & 14 & 5,9 & 4,5 & 11,9 & 13,2 & 91,0 & 24,2 & 167,1 \\
\hline $\begin{array}{l}90 \% \text { barley malt } \\
+10 \% \text { buckwheat } \\
\text { malt }\end{array}$ & 14 & 6,0 & 4,8 & 11,2 & 12,7 & 87,5 & 19,5 & 139,2 \\
\hline $\begin{array}{l}85 \% \text { barley malt } \\
+15 \% \text { buckwheat } \\
\text { malt }\end{array}$ & 14 & 5,9 & 4,1 & 9,5 & 11,9 & 82,1 & 13,4 & 92,4 \\
\hline
\end{tabular}

The best results in terms of reducing substances and amine nitrogen content showed a sample of wort, which was prepared from barley and buckwheat malt in the ratio of 95:5\%, respectively. You can also see a pattern that increasing the amount of buckwheat malt decreases the amount of reducing substances and amine nitrogen, this is due to the fact that buckwheat malt has a small amount of amylolytic and proteolytic enzymes [18, 19], so biologically active substances cannot be hydrolyzed and then extracted in solution $[18,19]$.

But in the production of low-gluten beer, enzyme preparations are not desirable to use, as they can harm people with celiac disease $[9,16]$.

Comparing the two types of wort (Figure 1,2), namely the wort made from light barley malt and crushed white buckwheat and barley malt and buckwheat malt, it was concluded that for brewing wort made from barley and buckwheat malt is better. This wort has the best physicochemical parameters, and buckwheat malt has enzymatic activity [12, 15], which allows you to hydrolyze more biologically active substances. This will further prepare lowgluten beer for prophylactic purposes [12, 15] with the best Physicochemical and organoleptic characteristics. 

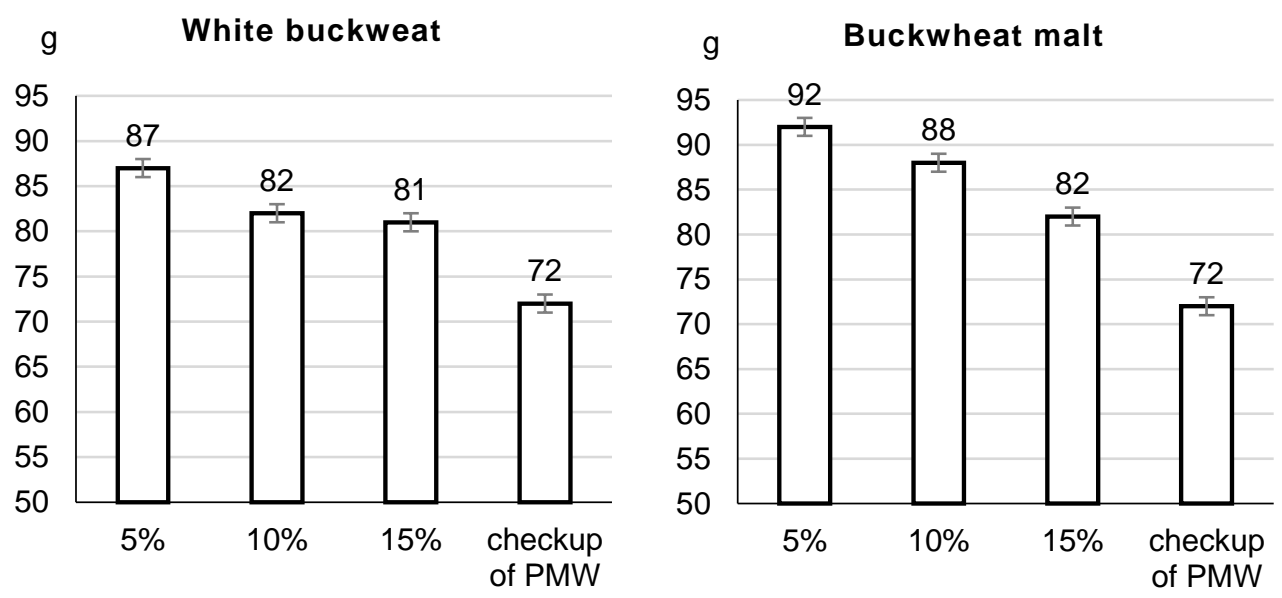

Figure 1. Content of reducing substances in malt wort from various buckwheat raw materials
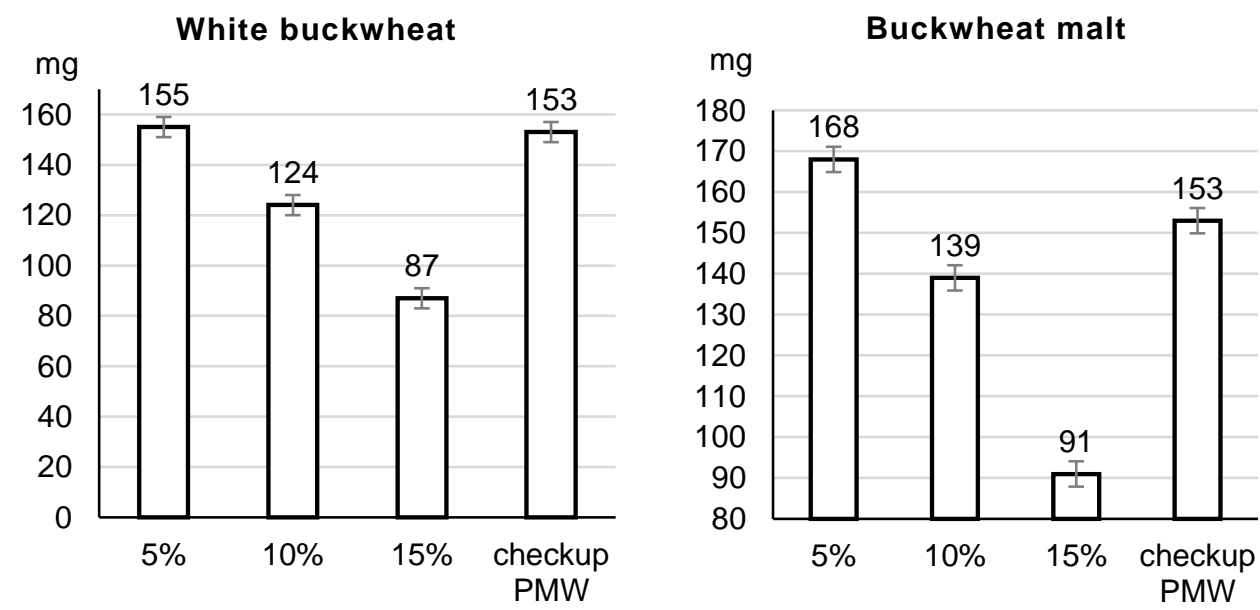

Figure 2. Content of amine nitrogen in malt wort from various buckwheat raw materials

\section{Analysis of finished beer}

The finished beer, prepared with partial replacement of barley malt with crushed white buckwheat and with partial replacement with buckwheat malt, had physicochemical parameters, which are presented in Tables 5 and 6 .

As the content of crushed white buckwheat increases, the amount of alcohol changes and the mass fraction of the actual extract decreases. This is due to the fact [19] that during the main fermentation with increasing amine nitrogen, the volume fraction of alcohol increases. 
Physicochemical parameters of finished beer with partial replacement

Table 5 of barley malt on crushed white buckwheat

\begin{tabular}{|c|c|c|c|c|c|c|c|}
\hline \multirow{2}{*}{$\begin{array}{c}\text { Beer } \\
\text { samples }\end{array}$} & \multirow{2}{*}{$\begin{array}{c}\text { Content of } \\
\text { dry } \\
\text { substance } \\
\text { in initial } \\
\text { wort, \% }\end{array}$} & \multirow{2}{*}{$\begin{array}{c}\text { Color, } \mathrm{cm}^{3} 0.1 \\
\text { mmol of iodine } \\
\text { solution per } \\
100 \mathrm{~cm}^{3} \text { of } \\
\text { wort }\end{array}$} & \multirow[b]{2}{*}{$\mathrm{pH}$} & \multicolumn{2}{|c|}{$\begin{array}{l}\text { Titrated acidity, } \\
\mathrm{mol} / \mathrm{dm}^{3}\end{array}$} & \multirow{2}{*}{\begin{tabular}{|} 
Content of \\
ethyl \\
alcohol, $\%$ \\
wt
\end{tabular}} & \multirow{2}{*}{$\begin{array}{c}\text { Mass } \\
\text { fraction of } \\
\text { the actual } \\
\text { extract, } \% \\
\text { wt }\end{array}$} \\
\hline & & & & $\begin{array}{c}\text { per } \\
100 \mathrm{~cm}^{3} \text { of } \\
\text { beer }\end{array}$ & $\begin{array}{l}\text { per } 100 \mathrm{~g} \\
\text { of extract }\end{array}$ & & \\
\hline Pure malt beer & 14 & 1,55 & 4,3 & 2,3 & 5,7 & 2,8 & 5,51 \\
\hline $\begin{array}{l}95 \% \text { barley } \\
\text { malt }+ \\
5 \% \text { crushed } \\
\text { white } \\
\text { buckwheat }\end{array}$ & 14 & 1,6 & 4,2 & 2,4 & 5,8 & 2,9 & 5,53 \\
\hline $\begin{array}{l}90 \% \text { barley } \\
\text { malt }+ \\
10 \% \text { crushed } \\
\text { white } \\
\text { buckwheat }\end{array}$ & 14 & 1,7 & 4,3 & 2,5 & 5,9 & 3,1 & 5,46 \\
\hline $\begin{array}{l}85 \% \text { barley } \\
\text { malt }+ \\
15 \% \text { crushed } \\
\text { white } \\
\text { buckwheat }\end{array}$ & 14 & 1,75 & 4,2 & 2,3 & 5,6 & 3,4 & 5,41 \\
\hline
\end{tabular}

Table 6

Physicochemical parameters of finished beer with partial replacement of barley malt with buckwheat malt

\begin{tabular}{|c|c|c|c|c|c|c|c|}
\hline \multirow{2}{*}{$\begin{array}{c}\text { Beer } \\
\text { samples }\end{array}$} & \multirow{2}{*}{$\begin{array}{l}\text { Content } \\
\text { of dry } \\
\text { substance } \\
\text { in initial } \\
\text { wort, \% }\end{array}$} & \multirow{2}{*}{$\begin{array}{c}\text { Color, } \mathrm{cm}^{3} \\
0.1 \text { mmol of } \\
\text { iodine } \\
\text { solution per } \\
100 \mathrm{~cm}^{3} \text { of } \\
\text { wort }\end{array}$} & \multirow{2}{*}{$\mathrm{pH}$} & \multicolumn{2}{|c|}{$\begin{array}{l}\text { Titrated acidity, } \\
\mathrm{mol} / \mathrm{dm}^{3} \mathrm{NaOH}\end{array}$} & \multirow{2}{*}{$\begin{array}{c}\text { Content of } \\
\text { ethyl } \\
\text { alcohol,\% } \\
\text { wt }\end{array}$} & \multirow{2}{*}{$\begin{array}{c}\text { Mass } \\
\text { fraction of } \\
\text { the actual } \\
\text { extract, } \% \\
\text { wt }\end{array}$} \\
\hline & & & & $\begin{array}{c}\text { per } 100 \\
\mathrm{~cm}^{3} \text { of beer }\end{array}$ & $\begin{array}{c}\text { per } 100 \mathrm{~g} \text { of } \\
\text { extract }\end{array}$ & & \\
\hline Pure malt beer & 14 & 1,55 & 4,25 & 2,3 & 5,74 & 2,9 & 5,51 \\
\hline $\begin{array}{l}95 \% \text { barley } \\
\text { malt }+ \\
5 \% \text { buckwheat } \\
\text { malt }\end{array}$ & 14 & 1,75 & 4,29 & 2,65 & 6,1 & 3,5 & 4,83 \\
\hline $\begin{array}{l}90 \% \text { barley } \\
\text { malt }+ \\
10 \% \\
\text { buckwheat } \\
\text { malt } \\
\end{array}$ & 14 & 1,80 & 4,35 & 2,60 & 5,98 & 3,7 & 4,91 \\
\hline $\begin{array}{l}85 \% \text { barley } \\
\text { malt }+ \\
15 \% \\
\text { buckwheat } \\
\text { malt } \\
\end{array}$ & 14 & 1,82 & 4,26 & 2,75 & 6,23 & 3,8 & 5,58 \\
\hline
\end{tabular}


With an increase in the content of buckwheat malt increases the amount of alcohol and increases the mass fraction of the actual extract (Figure 3,4). The best results showed a sample made from $95 \%$ barley malt and $5 \%$ buckwheat malt, as it had optimal results in alcohol content and the best results in mass fraction of real extract, because the smaller the mass fraction of real extract, the better the yeast fermented the wort $[12,15]$.
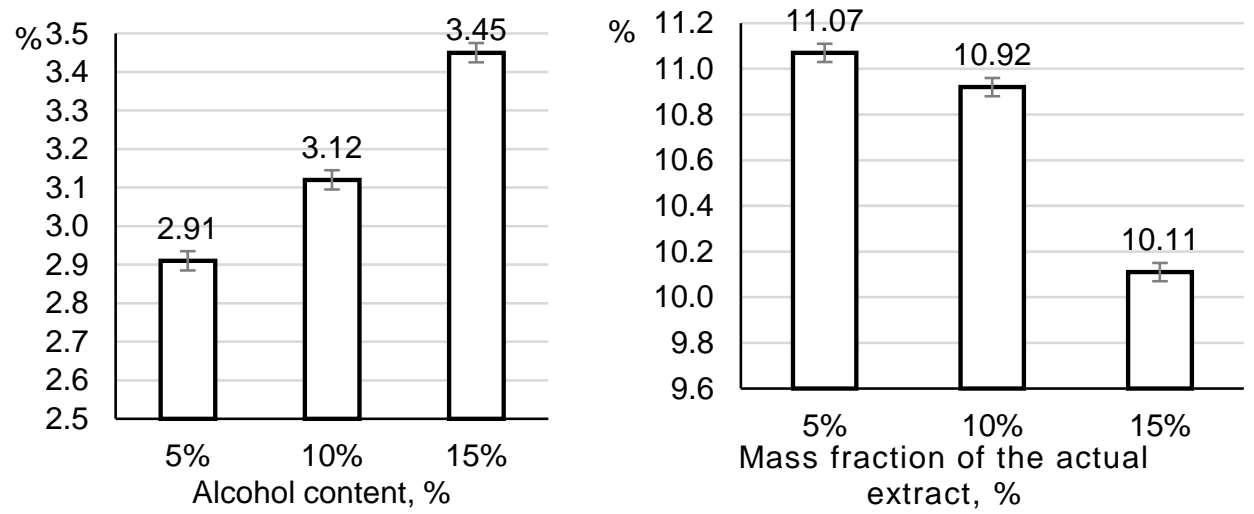

Figure 3. Effect of the amount of crushed white buckwheat on the content of ethyl alcohol and the mass fraction of the actual extract in the finished beer
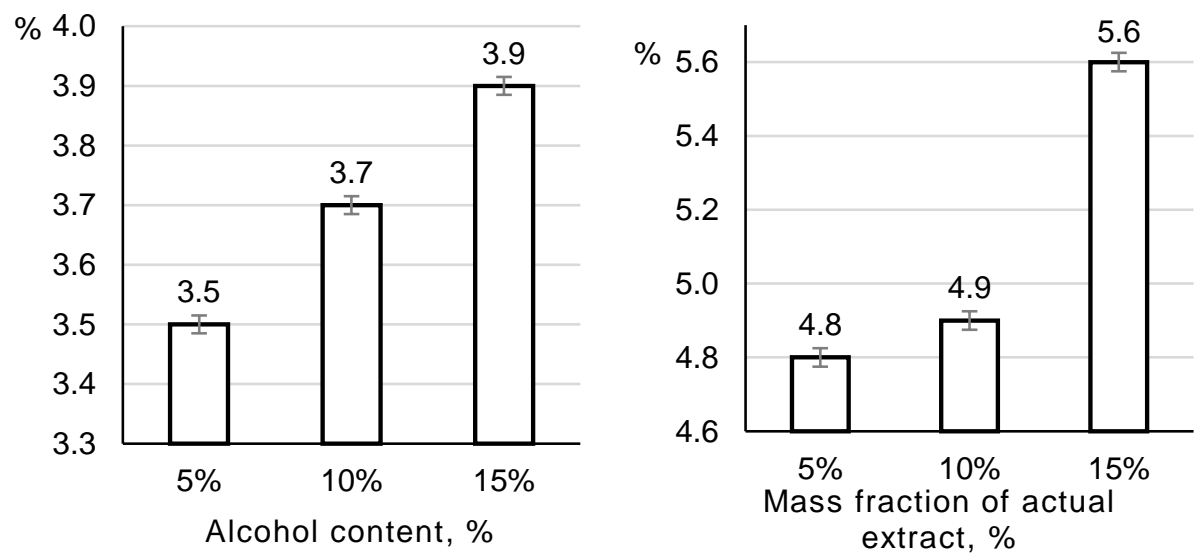

Figure 4. Effect of the amount of buckwheat malt on the content of ethyl alcohol and the mass fraction of the actual extract in the finished beer

\section{Conclusions}

The choice and quantity of unmalted raw materials - crushed white buckwheat and buckwheat malt for the production of low-gluten beer (95\% barley malt and 5\% buckwheat malt or crushed white buckwheat) are substantiated.

Beer brewed with a partial replacement of barley malt for buckwheat malt has better physicochemical properties than beer brewed with a partial replacement of barley malt for crushed white buckwheat.

For the production of low-gluten beer, it is recommended to use 5\% buckwheat malt as a low-gluten raw material. 


\section{References}

1. Tamashkina T.V., Semenjuta A.A., Trocenko A.S., Klykokov A.G. (2017), Bezgljutenovye slaboalkogol'nye napitki iz svetlogo i tomlennogo grechishnogo soloda, Pivo i napitki.

2. Petrova N.A., Oganesjan V.G., Ivanchenko O.B. (2011), Sposob prigotovlenija bezalkogol'nogo grechishnogo piva, Pivo i napitki, 5.

3. Novikova I.V., Korotki Y.A., Chusova A.Y., Pruakova V.Y. (2014), Assessment of the balance of malt extract when designing drinks special medical and biological properties, Hranenie i pererabotka selhoz syrja, 12, pp. 28-32.

4. Charles W. Bamforth (2006), Brewing. New technologies, Woodhead Publishing Limited, Cambridge, England.

5. Karpilenko G., Vitol S., Akimova O. (2004), Actes du siminarise. Madriseet question de la qualite dans lindustrie alimentaire, Tehnical NFO, Moldavie.

6. Korus J., Witczak M., Ziobro R. (2009), The impact of resistant starch on characteristics of gluten-free dough and bread, Food Hydricolloids, 23, pp. 988-995.

7. Norita N., Maeda T., Sai R., Miyake K. (2006) Studies on distribution of protein and allergen in graded fours prepares from whole buckwheat grains, Food Res. Intern, 39, pp. 782-790.

8. Shendry T., Bezhadete M., Runnin A. (2009) Celiac disease. A Guide to Successful diagnosis and treatment, The journal for Nurse Practitioners, 4, pp. 244-253.

9. Yano C., Hayakawa S., Torii S. (2012), Purificaton and properties of allergenis proteins in buckwheat seeds, Agris. Biol.Chem, 53(9), pp. 2387-2392.

10. Naiyana Gujral, Hugh I. Freeman, Alan Tromson (2012), Celias disease: Prevalence, diagnosis, pathogenases and treatment, World journal of gastroenterology, 18(42), pp. 60366059.

11. Volta U., Villanacci V. (2011), Celias disease: diagnostic criteria in progress, Cellular and molecular immunology, 8, pp. 96-102.

12. Ludwig Narzib (2007), Abrib der Bierbrauerei, Wiley-vch Verlag GmbH and Co.

13. Ciocan M., Dabija A., Codina G.G. (2020), Effect of some unconventional ingredient on the production of black beer, Ukrainian Food Journal, 9 (2), pp. 322-331.

14. Purificacion Saez-Plaza, Maria Jose Navas, Slatomir Wybraniec (2013), An overview of the Kjeldahl Method of Nitrogen Determination. Part 2. Sample Preparation, Working Scale, Instrumental Finish, and Quality Control, Critical Reviews in Analitical Chemistry, pp. 224272.

15. Wolfgang Kunze (2009), Technology brewing and malting, VLB, Berlin.

16. Matjaz Dezelak, Martin Zarnkow, Thomas Becker (2014), Processing of bottom-fermented gluten-free beer-like beverages based on buckwheat and quinoa malt with chemical and sensory characterization, Institute of Brewing and Distiling.

17. Guerdrum L.E., and Bamforth C.W. (2011) Levels of gliadin incommercial beers, Food Chem., 129, pp. 1783-1784.

18. Kuts A., Bulyi Yu., Zinchenko O. (2019), Improvemen of technology of low-calorie diet beer, Resource and Energy Saving Technologies of Production and Packing of Food Products as the Main Fundamentals of Their Competitiveness: Proceedings of the 7th International Specialized Scientific and Practical Conference, September 13, 2018. Kyiv, Ukraine, pp. 4954.

19. Tanashkyna T.V., Semenjuta A.A., Trocenko A.S., Klykov A.Gh. (2017), Bezghljutenovi slaboalkogholjni napoji iz svitlogho i fermentovanogho ghrechanogho soloda, Tekhnyka y tekhnologhija kharchovykh vyrobnyctv, 45(2), pp. 74-80.

20. Komynskyi H.Y., Morhunova E.M., Lysenko N.V. (2004), Razrabotka tekhnologhyy pyva s yspoljzovanyem ghrechykhy, Yzvestyia vuzov. Pyshchevaia tekhnolohyia, 4, pp. 37-39. 